\title{
MENYOAL POLITIK KEKERABATAN DI INDONESIA DALAM PELAKSANAAN PILKADA SERENTAK 2020
}

\author{
Mudiyati Rahmatunnisa \\ Departemen Ilmu Politik, FISIP, Universitas Padjadjaran \\ m.rahmatunnisa@unpad.ac.id
}

\begin{abstract}
Abstrak
Fenomena politik kekerabatan pada perhelatan Pilkada Serentak di 270 wilayah di Indonesia pada 9 Desember 2020 kembali terjadi, bahkan dengan tren peningkatan yang cukup signifikan jika dibandingkan dengan Pilkada Serentak 2015. Banyak pihak bersepakat bahwa fenomena politik kekerabatan merupakan salah satu sisi gelap demokratisasi di era reformasi Indonesia saat ini. Secara khusus, artikel ini bertujuan untuk menjelaskan serta menganalisis berbagai faktor yang telah berkontribusi pada munculnya fenomena politik kekerabatan pada Pilkada Serentak 2020. Selain itu, menjelaskan pula tentang konsekuensinya terhadap proses demokratisasi yang sedang berlangsung di Indonesia. Untuk menjawab pertanyaan tersebut, Penulis menggunakan metode kualitatif dengan studi literatur sebagai teknik pengumpulan data. Hasil analisis data menunjukkan bahwa tren politik kekerabatan dengan berbagai variannya merupakan implikasi logis dari disfungsi partai politik serta kuatnya pragmatisme partai politik dalam meraih kemenangan kontestasi elektoral. Karakter utama dari kekuasaan yang self-perpetuated dan dampak dari "name recognition" atau "brand name advantage" yang berkelindan dengan pragmatisme partai politik dan publik pemilih yang permisif juga diyakini telah berkontribusi signifikan terhadap maraknya politik kekerabatan. Sistem Pilkada yang candidate centered dan ketiadaan regulasi yang dapat memitigasi praktek politik kekerabatan juga menjadi penyebab penting lainnya dalam peningkatan tren politik kekerabatan ini pada Pilkada Serentak 2020. Praktek politik kekerabatan berpotensi mengakibatkan proses demokratisasi di Indonesia gagal dalam memfasilitasi potential benefits yang dijanjikan, jika tidak ada upaya memitigasinya.
\end{abstract}

Kata Kunci/Keywords: dinasti politik; pilkada; demokrasi; etika politik; rekrutmen politik.

\section{PENDAHULUAN}

Pemilihan Kepala Daerah secara langsung (Pilkada) di Indonesia telah menjadi agenda rutin sejak tahun 2005. Di satu sisi, Pilkada diapresiasi sebagai salah satu mekanisme positif dalam konteks penguatan demokrasi lokal (Sulistiyanto and Erb, 2009, p. 3; Hanif and Pratikno, 2012, p. 89). Namun, di sisi 
lain, pelaksanaannya masih diwarnai oleh berbagai permasalahan sebagaimana dikritisi banyak kalangan (Choi, 2007; Mboi, 2009; Aspinall and As'ad, 2016) . Salah satu yang menjadi sorotan dalam setiap perhelatan Pilkada adalah munculnya fenomena "politik kekerabatan" yang secara umum dipahami oleh banyak pihak sebagai fenomena kemunculan dan kemenangan pasangan pemimpin daerah yang memiliki kekerabatan dengan seseorang atau sejumlah orang dalam lingkaran kekuasaan di berbagai institusi politik atau pemerintahan, baik di tingkat Pusat maupun di Daerah.

Data menunjukkan bahwa dibandingkan dengan perhelatan Pilkada sebelumnya, politik kekerabatan pada Pilkada Serentak 2020 menunjukkan peningkatan cukup signifikan. Pasca KPU RI merilis daftar pasangan calon kepala daerah pada Pilkada Serentak 2020, Lembaga Riset Nagara Institute (2020) mencatat terdapat 124 kandidat pada Pilkada Serentak 2020 yang terafiliasi dengan dinasti politik, dengan perincian sebagai berikut:

a. $\quad 57$ calon bupati dan 30 calon wakil bupati;

b. 20 calon walikota dan 8 calon wakil walikota;

c. 5 calon gubernur dan 4 calon wakil gubernur.

Catatan menarik lainnya adalah dari total 124 kandidat tersebut, 57 perempuan dan 29 di antaranya adalah istri dari kepala daerah sebelumnya.

Salah satu yang fenomenal pada Pilkada Serentak 2020 adalah pencalonan dan kemenangan anak dan menantu Presiden Joko Widodo - Gibran Rakabuming Raka pada Pilkada Kota Surakarta dan Bobby Nasution pada Pilkada Kota Medan. Bahkan, ini menjadi catatan tersendiri karena untuk pertama kalinya di Indonesia, seorang Presiden yang tengah menjabat, memiliki anak dan menantu yang menjadi Kepala Daerah terpilih. Pola memunculkan anak atau menantu ini juga terjadi di Pilkada Kabupaten Kediri dan Sijunjung.

Selain itu, yang menarik lagi adalah di Kota Tangerang Selatan, di mana terdapat 3 pasangan kandidat yang semuanya memiliki kekerabatan dengan elite politik Daerah maupun Nasional. Adalah pasangan nomor urut 03 - Benyamin Dafnie dan Pilar Saga Ichsan di mana Pilar adalah anak dari calon Bupati Serang petahana, Ratu Tatu Chasanah. Sementara Ratu Tatu sendiri adalah adik kandung 
dari mantan Gubernur Banten, Ratu Atut Chosiyah sekaligus ipar dari Wali Kota Tangerang Selatan saat ini, Airin Rachmi Diany. Sementara itu, pasangan calon wali dan wakil walikota dengan nomor urut 02, yakni Siti Nur Azizah Ruhamaben, di mana Siti Nurazizah adalah anak dari Wakil Presiden KH. Ma'ruf Amin. Selanjutnya, pasangan nomor urut 01 - Muhamad dan Rahayu Saraswati, di mana Saraswati merupakan keponakan dari Prabwo Subianto.

Pola yang lain dari politik kekerabatan yang terjadi di Pilkada Serentak 2020 adalah dengan memunculkan istri dari petahana, yakni di Pilkada Provinsi Kepulauan Riau, Kabupaten Indragiri Hulu, Kabupaten Banyuwangi dan Kabupaten Buru Selatan. Selain istri, ada juga yang memunculkan adik dari petahana, seperti Pilkada Kabupaten Serang dan Kota Makasar, atau keponakan, seperti halnya di Kota Tangerang Selatan, yakni Pilkada Kabupaten Pangkajene dan Kepulauan.

Kenawas (2020) mengkonfirmasi meningkatnya kandidat yang berafiliasi dengan politik kekerabatan pada akhirnya akan semakin meningkatkan pertumbuhan politik kekerabatan yang menduduki pos-pos strategis di Daerah. Kenawas mencatat pertumbuhan 300 persen dari politik kekerabatan yang memenangkan Pilkada pada dalam kurun waktu 2015-2018, yakni sejumlah 117, dibandingkan dengan tahun 2013 sejumlah 39. Studi Nagara Institute (dalam The Indonesian Institute, 2020) juga mengkonfirmasi bahwa sampai dengan Pilkada 2018, dari 514 Daerah Otonom di Indonesia, 80 (14,78\%) diantaranya terpapar politik kekerabatan.Tren politik kekerabatan ini diperkirakan juga akan naik seiring dengan kemenangan para kandidat yang terpapar politik kekerabatan ini dalam Pilkada Serentak 2020. Secara agregat, pada akhirnya pemenang Pilkada 2020 yang terpapar politik kekerabatan ini, akan semakin meningkatkan jumlah pemimpin daerah otonom yang terpapar politik kekerabatan.

Argumentasi terkait tren kenaikan politik kekerabatan tersebut sejalan dengan proposisi yang dibangun oleh Dal Bo et al. (2009, p. 3) yakni bahwa semakin banyak dinasti atau keluarga politik yang menguasai pucuk pimpinan baik di pusat maupun di daerah, pada akhirnya akan semakin menumbuhkan politik 
kekerabatan seiring dengan semakin meluasnya arena politik yang diduduki oleh mereka dan kerabatnya.

Banyak pihak bersepakat memberikan respon negatif terhadap fenomena politik kekerabatan pada perhelatan Pilkada di Indonesia yang telah dilaksanakan beberapa kali sejak 2005 dan memandangnya sebagai salah satu sisi gelap demokratisasi di era reformasi Indonesia saat ini (Agustino, 2010; Purdey, Aspinall and As'ad, 2016; Sutisna, 2017). Apakah perspektif ini masih relevan untuk Pilkada Serentak 2020 yang baru lalu? Mengapa fenomena ini bisa terjadi dan bahkan menunjukkan tren yang semakin meningkat? Dengan kata lain, faktor apa yang telah menyebabkan munculnya fenomena politik kekerabatan? Apa konsekuensinya terhadap proses demokratisasi yang sedang berlangsung di Indonesia? Artikel ini bertujuan untuk mendiskusikan tiga pertanyaan mendasar tersebut dan merupakan fokus utama dalam artikel ini.

Sesungguhnya, suksesi dinastik (dynastic succession) terjadi di banyak profesi. Namun, perbedaan signifikan di profesi politisi terutama dalam sistem demokrasi adalah pada mekanisme suksesi yang harus melewati proses kontestasi elektoral. Inilah dasar argumentasi mengapa topik ini senantiasa menarik untuk didiskusikan. Penulis bersepakat dengan argumentasi bahwa salah satu prinsip penting yang terlanggar dan menjadi kritik banyak pihak terkait suksesi dinastik ini adalah proses kontestasi elektoral yang menjadi tidak fair dan menawarkan beragam privileges kepada kandidat yang terpapar politik kekerabatan (Besley 2005, dalam Geys and Smith, 2017, p. 475). Pada kondisi ini, kompetisi yang fair salah satu kriteria penting pemilihan umum yang berintegritas tidak terpenuhi, sebagaimana dinyatakan oleh Pippa Norris (2015, dalam Rahmatunnisa, 2017, p. 4) dalam bukunya yang berjudul "Why Electoral Integrity Matters". Demikian juga dikemukakan oleh Elkit dan Svensson (1997, p. 34) terkait pentingnya prinsip free and fair election sebagai prinsip penting pemilu berintegritas dalam rangka membentuk pemerintahan yang sah dan mendapatkan dukungan dari publik.

Diskursus apakah kekuasaan politik dapat diwariskan melalui pemilu bukanlah kajian baru. Zheng et a.l (2016, p. 7) dan van Coppenolle (2017, p. 3) menyatakan bahwa Roberto Michels, Gaetano Mosca dan Vilfredo Pareto 
merupakan ilmuwan politik awal yang membahas tentang keberadaan politik kekerabatan atau dinasti politik dalam konteks demokrasi perwakilan. Satu catatan penting dari pemikiran ketiga pemikir politik yang berpengaruh tersebut adalah terkait kenicscayaan konsentrasi kekuasaan pada sekelompok elit dan mereka sebagai kelas penguasa dapat memiliki kemampuan mengekalkan kekuasaannya di atas massa yang memang kurang terorganisir, termasuk dalam sistem demokrasi. Elit penguasa akan memiliki kecenderungan untuk “...keep a tight family grip on political office, especially if the private benefits of office exceed what can be gained outside of politics. More generally, the wealth, education, good genes and connections enjoyed within prominent elite families may help them to maintain their grip on power, even when faced with electoral competition." (Geys and Smith, 2017, p. 448). Argumentasi serupa juga dibangun oleh Dal Bó, Dal Bó and Snyder (2009, p. 115) berdasarkan studinya atas Kongres Amerika Serikat, di mana disimpulkan bahwa "dynastic political is self-perpetuating."

Studi tentang politik kekerabatan sudah banyak dilakukan, baik di berbagai negara di dunia maupun Indonesia. Misalnya, studi Dal Bó et al. (2009) dan Querubin (2016) serta Rossi (2016) yang membahas tentang pengaruh lamanya masa jabatan dari seorang politisi terhadap kecenderungan munculnya dinasti politik. Temuan penting dari studi ini adalah terkait lamanya masa jabatan seorang politisi yang dapat memberikan keuntungan bagi kerabatnya yang bertarung dalam kontestasi elektoral, karena nama keluarga yang telah dikenal atau jejaring politik yang telah kuat dan luas. Namun, temuan studi ini tidak serta merta menjadi temuan yang bisa digeneralisai, karena studi-studi lainnya membantah temuan ini, seperti misalnya studi van Coppenolle (2017) di Inggris dan Fiva dan Smith (2018) di Norwegia.

Studi lainnya juga membahas berbagai faktor yang telah menyebabkan dinasti politik muncul dan berkembang, seperti studi Buehler dan Tan (2007), Tusalem dan Pe-Aguirre (2013) misalnya. Namun focus kajian studi terdahulu hanya memfokuskan pada pembahasan tentang satu faktor penyebab dominan dan umumnya terkait dengan pemilu legislatif. Studi ini terkait erat dengan beberapa studi terdahulu terkait politik kekerabatan, namun setting Pilkada Serentak 2020 
memberikan nuansa yang berbeda terkait berbagai aspek praktek politik kekerabatan yang terjadi di Indonesia. Variasi pola, beragam faktor penyebab dan analisis berbagai dampak politik kekerabatan terhadap proses demokratisasi yang tengah berjalan serta prospeknya ke depan, menjadikan studi ini penting dan menyajikan perspektif yang dapat melengkapi diskursus politik kekerabatan di Indonesia dan juga pada bangunan literatur tentang politik kekerabatan secara umum.

Argumen utama yang dibangun dalam studi ini adalah tren politik kekerabatan yang menunjukkan tren peningkatan pada Pilkada Serentak 2020 di Indonesia dengan berbagai variannya baik intra- mauppun inter-generational, merupakan implikasi logis dari berbagai kondisi yakni disfungsi partai politik dalam proses kaderisasi dan rekrutmen yang efektif serta kuatnya pragmatisme partai dalam meraih kemenangan kontestasi elektoral. Selain itu, meningkatnya prevalensi dinasti politik juga merupakan konsekuensi logis dari karakter kekuasaan yang self-perpetuated dan dampak dari "name recognition" atau "brand name advantage" yang berkelindan dengan pragmatisme partai politik dan publik pemilih yang permisif. Sistem Pilkada yang candidate centered dan ketiadaan regulasi yang dapat memitigasi praktek politik kekerabatan ini juga telah menjadi penyebab lain meningkatnya tren politik kekerabatan pada Pilkada Serentak 2020. Penulis bersepakat dengan analisis banyak ahli bahwa praktek politik kekerabatan potensial untuk dapat mengakibatkan proses demokratisasi di Indonesia gagal memfasilitasi potential benefits yang dijanjikan, jika tidak ada upaya memitigasinya.

Sintesa yang di bangun dalam studi ini berasal dari berbagai konsep dan teori yang telah berkembang dari para ahli dan juga lessons learned dari studi-studi terdahulu yang relevan. Sintesa inilah yang menjadikan studi ini berbeda karena konstruksi kerangka analisis yang lebih komprehensif untuk dapat menganalisis praktek-praktek terkini dari politik kekerabatan yang berlangsung di era reformasi Indonesia saat ini, dan khususnya di Pilkada Serentak 2020.

Setelah uraian Pendahuluan ini, bagian selanjutnya akan menjelaskan secara singkat metode yang digunakan dalam rangka menjawab pertanyaan- 
pertanyaan yang diajukan dalam studi ini. Kemudian diskusi dan analisis atas pernyataan-pertanyaan pokok menjadi isi utama dari sub-bagian ketiga dari artikel ini. Bagian terakhir memuat simpulan singkat atas temuan utama studi ini.

Dalam rangka menjawab pertanyaan-pertanyaan yang diajukan dalam studi ini, Penulis menggunakan metode kualitatif dengan studi kepustakaan atau literatur sebagai teknik pengumpulan data. Metode kualitatif dipandang tepat karena studi ini tidak bermaksud untuk melakukan generalisasi atas fenomena emipitik yang dikaji. Pendekatan kualitatif memberikan peluang untuk dapat memahami secara mendalam terkait fenomena politik kekerabatan atau dinasti politik pada perhelatan Pilkada Serentak 2020 yang berlangsung di 270 daerah di Indonesia dengan jumlah kasus 3 kali lipat jika dibandingkan dengan Pilkada Serentak 2015 (Kenawas, 2020). Untuk mendiskusikan jawaban atas pertanyaan-pertanyaan yang diajukan serta membangun argumen, Penulis menggunakan data-data sekunder melalui kajian sumber pustaka yang relevan dan otoritatif. . Berbagai buku, artikel jurnal ilmiah terkini, relevan dan otoritatif, menjadi sumber data utama. Demikian juga berbagai pemberitaan dari beberapa media otoritatif menjadi sumber data pelengkap lainnya. Berbagai sumber pustaka tersebut, memberikan data-data yang relative lengkap untuk menjawab pertanyaan penelitian yang diajukan dalam studi ini.

Proses trianggulasi sumber digunakan untuk memvalidasi data yang diperoleh. Adapun analisis data dilakukan dengan progressive focusing yaitu dengan melakukan pengumpulan dan interpretasi dari berbagai literature dan data yang telah dikumpulkan serta bagaimana relevansinya dengan pertanyaanpertanyaan pokok dari studi ini (textual and interpretative analysis). Penulis menyesuaikan proses pengumpulan data ketika konsep tambahan perlu diteliti atau hubungan baru perlu dieksplorasi (Parlett \& Hamilton 1976, dalam Schutt, 2012, p. $322)$.

Penyelenggaraan Pilkada Serentak 2020 di 270 daerah di Indonesia menjadi setting utama dalam membahas pertanyaan-pertanyaan yang diajukan dalam studi ini. Lama waktu penelitian berlangsung selama 3 bulan dengan periode amatan 
dalam konteks Pilkada Serentak 2020 adalah dari September 2020 sampai dengan Januari 2021.

\section{PEMBAHASAN}

Politik kekerabatan bukanlah monopoli Indonesia. Prakteknya dapat ditemui di berbagai Negara di dunia, termasuk Negara-negara dengan sistem demokrasi yang mapan. Misalnya Amerika Serikat yang sering di daulat sebagai kiblatnya demokrasi, ada keluarga Kennedy dan Bush serta Clinton. Kemudian keluarga Nehru dan Gandhi di India, keluarga Bhuto di Pakistan, Trudeau di Kanada dan Allende di Chile merupakan beberapa contoh dinasti politik. Filipina juga tidak kalah spektakuler dalam praktek politik kekerabatan. Lebih dari setengah anggota legislatif dan gubernur yang terpilih, memiliki kerabat yang menduduki posisi strategis di berbagai lembaga pemerintah. Bahkan, $40 \%$ dari 79 provinsi yang ada, gubernur dan anggota legislatifnya merupakan kerabat (Querubin, 2013, p. 2).

Beragam kajian terkait politik kekerabatan telah berkonsekuensi pada keragaman definisi konsep dinasti politik oleh banyak ahli. Menurut Geys dan Smith (2017, p. 446) misalnya, secara luas mendefinisikan dynastic politicians sebagai "politicians who are related by blood or marriage to other individuals formerly holding political office." Definisi ini secara substantif sama dengan yang dikemukakan oleh Dal Bó et al. (2009, p. 2) dengan subjek bahasan dalam studinya tentang anggota Kongres Amerika Serikat. Dijelaskan bahwa "dynastic legislator" adalah mereka yang berasal dari keluarga yang telah memiliki anggota keluarga di Kongres sebelumnya. Menggunakan istilah "dynastic politicians", Asako et al. (2015, p. 5) juga merujuk kepada politisi yang memiliki kerabat yang telah menduduki jabatan yang sama di lebih dulu. Pemaknaan sempit dari dinasti politik menurut Geys dan Smith (2017, p. 446) hanya merujuk pada “...politicians that succeed a relative in the same jurisdiction immediately following the departure of their predecessor..."

Studi Purdey, Aspinall dan As'ad (2016, pp. 3-4) melengkapi pengertian dinasti politik, dan membedakannya dengan konsep political family (keluarga politik). Keluarga politik merujuk pada sebuah keluarga di mana lebih dari satu 
anggota keluarga memperoleh posisi politik dalam satu wilayah geografis (Daerah Otonom). Dimensi lainnya dari kekuasaan keluarga politik ini adalah tersebarnya anggota keluarga tersebut di berbagai pos-pos politik strategis baik legislatif maupun eksekutif, tidak hanya di dalam satu daerah otonom saja, akan tetapi juga daerah-daerah di sekitarnya (kabupaten/kota atau provinsi). Keluarga politik dapat menjadi dinasti politik manakala mampu melebarkan kekuasaanya, sehingga ketika mengalami kekalahan kontestasi elektoral, yang bersangkutan akan diteruskan oleh pasangan (suami atau istri, atau) kerabat lainnya (intra-generational), atau oleh anak atau menantunya (inter-generational).

Dengan merujuk pada berbagai pengertian dinasti politik di atas, maka apa yang telah berlangsung pada Pilkada Serentak 2020 jelas menunjukkan maraknya fenomena politik kekerabatan ini, dengan berbagai varianny., Dalam konteks keluarga Presiden Jokowi ini memenuhi karakteristik political family dan newly political dynasty.

Varian dinasti politik intra-generational juga menjadi yang cukup signifikan terjadi, ketika istri dari petahana melaju untuk berkontestasi, seperti yang terjadi misalnya di Pilkada Kabupaten Bandung, Kabupaten Banyuwangi, Kota Batam, dan Kabupaten Sleman. Atau kerabat dari petahana atau tokoh politik di berbagai institusi pemerintah, baik Pusat maupun Daerah, seperti yang terjadi di Pilkada Kota Tangerang Selatan, Kota Makasar, dan Kediri. Demikian halnya dengan varian dinasti politik inter-generational, di mana anak atau menantu menjadi successor dari founder dinasti politik, misalnya terjadi di Pilkada Kabupaten Serang, Kota Tangerang Selatan, dan Kota Medan.

Berbagai studi telah menunjukkan beragam faktor potensial yang menjadi penyebab atau memfasilitasi munculnya dinasti politik ini dan menurut Penulis relevan dalam konteks Pilkada Serentak 2020 lalu, yakni:

a. Belum berjalannya proses pelembagaan, kaderisasi dan rekrutment politik secara efektif yang seharusnya dilakukan partai politik (Romli, 2008, pp. 2930). Kondisi ini berkelindan dengan pragmatisme partai politik untuk memenangkan kontestasi elektoral dan hanya tertarik mengusung kandidat yang memiliki modal ekonomi, politik dan sosial yang kuat, meskipun bukan kader 
partai. Menurut Buehler dan Tan (2007, p. 42), "getting funds was a primary purpose behind the party's choice of candidate..." Akibatnya, kelompok elit lokal, termasuk keluarga politik yang kuat secara ekonomi (memiliki jejaring bisnis yang kuat) dan politik, yang kemudian mendominasi politik lokal (Buehler and Tan, 2007; Mietzner, 2010; Tusalem and Pe-Aguirre, 2013; Purdey, Aspinall and As'ad, 2016). Argumentasi ini relevan dan dan terkonfirmasi pada Pilkada Serentak 2020. Dalam konteks argumentasi ini, jika diamati, banyak kandidat yang terpapar dinasti politik atau keluarga politik, bukanlah kader partai yang telah lama berkecimpung sebagai anggota atau pengurus partai politik, diantaranya kasus Gibran Rakabuming Raka dan juga Bobby Nasution yang baru bergabung menjadi anggota PDI-P menjelas Pilakda 2020, mengalahkan kandidat lain yang merupakan kader lama dari PDI-P. Demikian halnya dengan kandidadi Ipuk Fiestiandani di Pilkada Banyuwangi 2020, yang merupakan istri dari petahana. Ipuk yang bukan kader partai, menyingkirkan Yusuf Widyatmoko ( cnnindonesia.com, 2020b, 2 September).

b. Prevalensi politik kekerabatan baik varian inter- maupun intra-generational, terutama dari petahana yang telah habis masa jabatannya pada Pilkada Serentak 2020 di beberapa daerah, mengkonfirmasi premis beberapa ahli bahwa pada prinsipnya kekuasaan politik itu self-perpetuated, yakni keinginan untuk tetap eksis (Dal Bó, Dal Bó and Snyder, 2009; Rossi, 2009). Kecenderungan selfperpetuation ini tidak terlepas dari berbagai motif. Studi Buehler (2013) misalnya, menunjukkan bahwa membangun dinasti politik merupakan " $a$ protection strategy: incumbents want to be succeeded by their family members in order to shield themselves and their 'nearest and dearest' from being jailed for corruption." Buehler menjustifikasi argumentasi yang dibangunnya dengan menunjukkan minimnya pemenjaraan pemimpin daerah yang kepemimpinannya diteruskan oleh istri, anak atau kerabatnya, karena kasus korupsi atau penyalahgunaan kekuasaan lainnya. Motif lain yang tidak kalah penting adalah untuk mengabadikan akses melalui kekuasaan politik terhadap berbagai sumberdaya (resource rents) yang ada di daerahnya dalam rangka memperluas kekayaan keluarga (Purdey, Aspinall and As'ad, 2016) 
c. Faktor lain yang telah memfasilitasi munculnya kandidat yang terpapar politik kekerabatan pada Pilkada Serentak 2020 adalah terbukanya peluang memanfaatkan apa yang disebut dengan "name recognition" atau "brand name advantage" (Dal Bó, Dal Bó and Snyder, 2009; Zheng et al., 2016) yang berkelindan dengan partai politik yang pragmatis (Tusalem and Pe-Aguirre, 2013) dan publik yang juga pragmatis dan permisif terhadap kehadiran keluarga dan dinasti politik. Argumentasi terkonfirmasi pada kandidat yang berasal dari keluarga politik atau petahana (tenure effect) di banyak Daerah di Indonesia, seperti dinasti Ratu Atut Chosiyah di Banten misalnya. Publik pemilih tentunya telah mengenal dan memiliki referensi yang lebih baik dari Keluarga politik dan petahana, dibandingkan dengan pendatang baru. Meskipun, referensi ini dapat menjadi boomerang manakala kinerja pendahulunya dipandang buruk oleh pemilih yang objektif dan mempertimbangkan aspek akuntabilitas. Dengan kata lain, familial recognition atau brand name tidak serta merta menjadi jaminan kemenangan elektoral pada akhirnya. Argumentasi ini sesuai dengan apa yang dikemukakan oleh, misalnya, Purdey, Aspinal dan As'ad (2016) dan Zheng et al. (2016).

d. Masih berkaitan dengan name atau familial recognition, studi Doyle et al. (2015) dan Geys dan Smith (2017, p. 449) menunjukkan bahwa politik kekerabatan marak ketika sistem pemilu berkarakter candidate-centered daripada party-centered. Kedua studi ini menunjukkan bahwa dalam system pemilu yang seperti itu, yang mendapat insentif lebih adalah kandidat yang berafiliasi dengan keluarga atau dinasti politik, karena efek dari name recognition, tidak hanya untuk pemilih, akan tetapi juga bagi partai politik pada saat seleksi kandidat. Dengan tidak berjalannya proses kaderisasi, maka partai politik ketika melakukan penentuan kandidat yang diusung akan berdasarkan pada "personalism, popularity, and name recognition." (Rogers, 2004). Fenomena kemenangan kandidat yang memiliki ikatan kekerabatan dengan elit politik maupun petahana seperti di Kabupaten Gowa dan Kabupaten Soppeng yang terafiliasi dengan dinasti Limpo. 
e. Beberapa ahli berpendapat bahwa ketiadaan peraturan yang melarang politik kekerabatan (anti-political dynasty regulation) menjadi salah satu faktor yang telah menyuburkan keberadaannya. Argumentasi ini sejalan dengan McCoy (1994, p. xvii., dalam Querubin, 2013, p. 3) misalnya, ketika Filipina menetapkan aturan konstitusional tentang pembatasan masa jabatan (term limits) untuk semua aparat yang dipilih, mengatakan bahwa atuan ini berpotensi memutus pengaruh politik kekerabatan “...through both universal limits and specific prohibition on relatives (...) holding any public office." Pendapat serupa juga dikemukakan oleh Purdey et al (2016) bahwa maraknya politik kekerabatan di Filipina salah satunya disebabkan oleh kegagalan melaksanaan aturan konstitusional melalui peraturan perundangan. Demikian halnya dengan publik Indonesia yang menyepakati bahwa tren meningkatnya politik kekerabatan merupakan akibat dari ketiadaan regulasi tersebut. Meskipun tentunya, keberadaan peraturan yang melarang dinasti politik, bukan merupakan satu-satunya cara.

Pada Pilkada Serentak 2020, respon negatif berbagai kalangan juga tidak terlepas dari beragam dampak negatif yang dapat ditimbulkan, khususnya terhadap proses demokratisasi Indonesia yang tengah bergulir. Kekhawatiran tersebut sejalan dengan berbagai kalkulasi teoritik maupun empirik yang dikontruksi para ahli.

Menurut Geys dan Smith (2017), praktek politik kekerabatan dapat menurunkan kualitas keterwakilan sebagai akibat dari mekanisme akuntabilitas lemah dan menghalangi munculnya kandidat lain yang berkualitas. Proses kontestasi politik tidak dapat berfungsi sebagai mekanisme akuntabilitas untuk mengganti petahana yang berkinerja buruk ketika transmisi kepemimpinan politik dilakukan kepada kerabat. Keberadaan dinasti politik juga seringkali tidak menyediakan pilihan kandidat alternatif untuk pemilih, karena proses rekrutmen kandidat yang tidak fair dan memberikan privilege kepada kerabat petahana (Besley 2005, dalam Geys and Smith, 2017).

Teori elit klasik dengan tokohnya Roberto Michels, Gaetano Mosca dan Vilfredo Pareto juga sudah lama memperingatkan keberadaan elit politik yang membangun keluarga dan dinasti politik sejatinya "violates the very essence and 
existence of a liberal democracy" terutama karena mereka dapat menghindarkan diri dari tuntutan akuntabilitas. Korupsi dan berbagai perilaku rent-seeking menjadi konsekuensi yang logis sebagai akibat dari ketiadaan mekanisme akuntabilitas yang efektif, baik vertikal maupun horizontal (Tusalem and Pe-Aguirre, 2013, p. 365). Kasus korupsi yang terjadi di Kabupaten Kutai Timur menjadi salah satu buktinyata argumentasi ini (cnnindonesia.com, 2020a, 5 Juli ). Negasi terhadap akuntabilitas ini pada akhirnya juga berimplikasi pada ketiadaan insentif untuk memberikan pelayanan maksimal kepada masyarakat, bahkan sebaliknya sumberdaya yang ada justru disalahgunakan untuk memenuhi kepentingan keluarga dan dinasti politik yang berkuasa. Argumentasi ini sejalan dengan penjelasan Tusalem and Pe-Aguirre (2013, p. 360) tentang bagaimana dinati politk berkelindan dengan korupsi dan buruknya pelayanan publik dan pembanguna ekonomi.

If reelection is driven not by consistent performance but rather by pedigree and client-patron relations preceding the elections, there is less incentive to pursue long-term infrastructure projects and policy reforms that provide incremental benefits. For example, it is a common feature for dynastic families to use political office as a means of rent seeking as they buy votes (a private good) through bribery or corrupt deals, or use their political influence to accumulate personal wealth. Ultimately, resources that should be devoted to economic and infrastructure development programs may be misappropriated.

Dalam konteks pelayanan publik ini, Robert Dahl (2000) juga menjelaskan bahwa demokrasi yang fungsional ditemukan pada Negara-negara yang Pemerintahannya mampu mendistribusikan pelayanan publiknya dengan baik. Sistem demokrasi yang fungsional terbentuk manakala kepercayaan yang diberikan oleh publik kepada pemerintah yang terpilih diwujudkan dalam bentuk pelayanan publik yang optimal. Ketika Pemerintahan ini dipandang gagal dalam memberikan pelayanan publik, maka tidak akan dipilih lagi dalam pemilu berikutnya. Oleh karena itu, dalam sistem demokrasi yang efektif, rakyat berdaya melalui sebuah mekanisme yang dibangun di atas kepercayaan dan kinerja yang mempromosikan standar akuntabilitas dan daya tanggap yang lebih tinggi dalam sistem politik, yang pada gilirannya akan meningkatkan kualitas hidup warga negara (OECD, 2013). 
Studi para ahli menunjukkan bahwa kualitas system demokrasi menjadi rendah akibat mekanisme akuntabilitas dirusak oleh keberadaan keluarga dan praktek sistemik politik kekerabatan di berbagai institusi politik, sebagaimana terjadi di Negara Filipina misalnya (Hutchcroft and Rocamora, 2003). Demikian halnya studi Setyaningrum dan Saragih (2019) di 250 Daerah di Indonesia yang menunjukkan efek negatif politik kekerabatan terhadap kinerja pemerintah daerah.

Dalam artikelnya, Buehler (2013) juga menambahkan bahwa fenomena keluarga dan dinasti politik menunjukkan adanya permasalahan serius dalam system politik yang berjalan. Permasalahan serius tersebut pada prinsipnya merusak integritas demokrasi lokal karena: (1) kemenangan klientelisme atas programprogram kandidat; (2) kemenangan jejaring informal atas peran partai politik; (3) kekalahan reformasi politik oleh perilaku koruptif dan predatory.

Berdasarkan pengalaman di Filipina misalnya, dominasi dinasti politik pada gilirannya akan melemahkan peran partai politik dalam mengagregasi dan mengartikulasi kepentingan konstituennya dan masyarakat pada umumnya. Partai politik pada akhirnya hanya akan menjadi alat atau kendaraan keluarga dan dinasti politik yang berkuasa (Tusalem and Pe-Aguirre, 2013, pp. 362-363). Lemahnya pelembagaan partai politik pada gilirannya juga akan semakin menyuburkan praktek dinasti politik (Hutchcroft and Rocamora, 2003). Kondisi ini tentu saja sangat tidak kondusif untuk konsolidasi demokrasi yang menghendaki berfungsinya partai politik secara efektif (Beetham, 1994; Randall and Svåsand, 2002).

Aspek lain dari politik kekerabatan yang mengancam kesehatan demokrasi adalah menguatnya “...a culture of client-patron relations wherein dynastic incumbents deliver public goods only when the next scheduled elections are around the corner. Dynastic families look at political office as rents, using resources allocated for economic and infrastructure development to buy votes (a private good) or accumulate wealth." (Tusalem and Pe-Aguirre, 2013, p. 366). Dalam konteks ini, patron (dinasti politik) hanya membangun hubungan dengan clients (pemilih) yang telah dan akan selalu loyal memberikan suaranya dengan pemberian berbagai barang politik (political goods) berupa jabatan, promosi, atau fasilitas 
lainnya sebagai imbalan. Dengan proses seperti ini, maka dynastic patrons akan terisolasi dari kekalahan elektoral selama mereka dapat mengendalikan perilaku clients. Praktek seperti ini menurut Tusalem dan Pe-Aguirre (2013, p. 366) pada gilirannya juga akan “... undermines the basic tenet of good governance: that both proponents and opponents of those in power are all equally entitled to public goods and services..." Dengan kata lain, yang akan menikmati keuntungan politik maupun barang publik lainnya hanyalah mereka yang dipandang loyal terhadap dynastic patron.

Sebetulnya potensi efek negatif politik kekerabatan tidak hanya pada partai politik, tetapi juga pada lembaga lainnya. Studi Acemoglu dan Robinson (2008) di Negara-negara Amerika Latin dan Querubin (2013) di Filipina serta Asako et al. (2015) di Jepang misalnya menunjukkan bahwa politik kekerabatan juga telah merusak tatanan ekonomi melalui berbagai berbagai kebijakan parsial yang hanya menguntungkan yang hanya menguntungkan sekelompok elite dan pemilik modal yang terkoneksi dengan dinasti politik. Ketimpangan ini pada akhirnya akan memperburuk kinerja pemerintah dalam pembangunan ekonomi.

Berbagai dampak negatif politik kekerabatan terhadap proses demokratisasi tersebut terkonfirmasi juga dialami oleh Indonesia pasca runtuhnya rezim Orde Baru, sebagaimana ditunjukkan berbagai studi yang dilakukan oleh para ahli. Dalam konteks ini, sebagian besar sepakat bahwa politik kekerabatan melemahkan demokrasi Indonesia. Studi Kenawas (2017) menunjukkan bahwa kehadiran politik kekerabatan telah menjadi by product dari proses desentralisasi dan demokratisasi di level daerah. Alih-alih menghilangkan konsentrasi kekuasaan, yang terjadi adalah monopoli kekuasaan oleh local strongmen melalui pembentukan dinasti politik. Lebih lanjut, Kenawas (2017, p. 271) mengatakan bahwa politik kekerabatan pada akhirnya akan merusak legitimasi dan kredibilitas dari desentralisasi dan demokratisasi di aras lokal .

Analisis Kenawas tersebut sejalan dengan apa yang digambarkan oleh Hadiz (2004) pada masa awal era reformasi bergulir. Keberadaan local strongmen melalui jalur politik kekerabatan dinilai telah menjadi salah satu sebab gagalnya twin processes desentralisasi dan demokratisasi dalam memfasilitasi potential 
benefits yang dijanjikan seperti good governance dengan pilar utamanya transparansi dan akuntabilitas, serta partisipasi politik yang luas seperti dikonstruksi oleh neo-institutionalists seperti Crook dan Manor (1998, p. 699). Argumentasi ini juga sejalan dengan konstruksi pemikiran Geys dan Smith (2017) serta Tusalem dan Pe-Aguirre (2013) terkait lemahnya mekanisme akuntabilitas sebagai akibat dari praktek dinasti politik.

Demikian juga analisis Trajano dan Yoes (2013, dalam Mariana and Husin, 2017 , p. 89) yang menunjukkan bahwa politik kekerabatan akan merusak tatanan proses demokratisasi karena terbatasnya partisipasi politik sebagai akibat dari monopoli proses elektoral melalui transfer kekuasaan kepada kerabat. Dalam konteks ini, Mariana dan Husin juga mengilustrasikan argumentasi ini dengan dinasti Atut Chosiyah di Banten dan dinasti Yasin Limpo di Sulawesi Selatan. Selain monopoli proses-proses elektoral, politik kekerabatan juga menafikan partisipasi politik masyarakat dalam berbagai proses-proses politik lainnya.

Lebih lanjut, dengan merujuk analisis Fukuoka, Mariana dan Husin (2017, p. 91) mengatakan bahwa sebagai akibat praktek politik kekerabatan, "political transition in Indonesia as a journey to an illiberal type of democracy: namely, oligarchical democracy." Dalam tatanan demokrasi oligarkis seperti ini "political contestation remains confined to a competing predatory interests, leading to the marginalisation of civil society forces." Dalam konteks argumentasi inilah, politik kekerabatan sebagaimana juga dikonstruksikan oleh Hadiz (2004) dapat mereduksi fasilitasi demokrasi dalam memperkuat partisipasi politik masyarakat. Lebih spesifik, politik kekerabatan erat kaitannya dengan ketidaksetaraan politik, akan sulit menciptakan "a fair political battlefield" untuk kandidat di luar dinasti politik dalam perhelatan kontestasi elektoral (Mariana and Husin, 2017, p. 91).

Kekhawatiran serupa terkait dampak politik kekerabatan terhadap proses demokratisasi juga cukup kuat disuarakan banyak kalangan ketika Pilkada 2020 bergulir. Aktifis kepemiluan Titi Anggraini (voaindonesia.com, 5 Juli 2020) misalnya, mengatakan bahwa meski diakui bahwa politik kekerabatan tidak dilarang karena dalam berdemokrasi setiap warga Negara memiliki kesetaraan hak untuk mengikuti kontestasi elektoral, namun yang perlu dicegah adalah praktek 
proses rekrutmen yang tidak demokratis, ekslusif dan cenderung secretive serta minim partisipasi kader dan pengurus partai serta publik pada umumnya.

Sulit untuk tidak mengatakan bahwa praktek seperti ini berdampak buruk terhadap proses demokratisasi Indonesia. Argumentasi banyak pengamat terkait demokratisasi Indonesia yang illiberal, ekslusif dan elitis, dibajak oleh predatory interests, dekat dengan perilaku koruptif, lemah dalam akuntabilitas dan transparansi serta belum mampu memfasilitasi output kinerja good governance, sebagai akibat dari praktek politik kekerabatan yang dipertontonkan sejak diberlakukannya Pilkada memang terkonfirmasi secara empirik (Hadiz and Robison, 2005; Choi, 2007; Hadiz, 2007; Hanif and Pratikno, 2012; Mariana and Husin, 2017). Penulis berpendapat bahwa potensi buruk berpeluang untuk terjadi di masa mendatang sebagai dampak dari semakin naiknya tren dinasti politik pasca Pilkada Serentak 2020, jika tidak disertai dengan upaya memitigasi potensi-potensi buruk tersebut dengan berbagai strategi yang tepat, komprehensif dan berkesinambungan.

\section{KESIMPULAN}

Artikel ini telah mendiskusikan tentang fenomena dinasti politik yang menunjukkan peningkatan cukup sigifikan pada Pilkada Serentak 2020 dan diyakini merupakan output dari berbagai faktor penyebab yang berkaitan satu sama lain, seperti masih lemahnya pelembagaan dan kuatnya pargmatisme partai politik untuk memenangkan kontestasi elektoral. Kondisi ini berkelindan dengan karakter kekuasaan yang self-perpetuation dan publik yang juga pragmatis dan permisif terhadap kehadiran keluarga dan dinasti politik serta teralienasi dari penilaian objektif terhadap kinerja dan program-program kerja yang ditawarkan. Penyebab lainnya yang tidak kalah penting adalah ketiadaan instrumen hukum yang dapat memitigasi efek buruk praktek dinasti politik, seperti ekslusifitas proses rekrutmen dan praktek korupsi.

Studi di berbagai Negara di dunia termasuk di Indonesia telah menunjukkan berbagai dampak negatif praktek dinasti politik khususnya terhadap proses demokratisasi. Alih-alih menuju ke arah consolidated democracy, praktek dinasti 
politik sejak bergulirnya Pilkada di 2005 justru telah berkontribusi signifikan terhadap label demokrasi Indonesia yang illiberal, elitis, oligarkis dan koruptif yang disematkan banyak ahli dan pengamat.

Prospek demokrasi Indonesia ke depan tidak akan jauh berbeda dengan kondisi yang sekarang jika tidak ada kemauan politik yang kuat dari semua elemen bangsa untuk mengatasi dampak buruk praktek dinasti politik. Pembenahan partai politik menjadi salah satu awal yang sangat penting, karena banyak praktek dinasti politik, berawal dari dinasti politik pada partai politik. Tak kalah penting adalah penguatan regulasi pemilu yang dapat menjamin terwujudnya level of playing field yang fair dan partisipatif. Last but not least, proses voters' political education menjadi pelengkap strategis untuk memitigasi dampak buruk dinasti politik.

\section{DAFTAR PUSTAKA}

Acemoglu, D. and Robinson, J. (2008) 'Persistence of Power, Elites, and Institutions', American Economic Review, 98, pp. 267-293. doi: 10.2139/ssrn.888187.

Agustino, L. (2010) 'Dinasti Politik Pasca-Otonomi Orde baru: Pengalaman Banten', Prisma, 29(3), pp. 102-116.

Asako, Y. et al. (2015) 'Dynastic politicians: Theory and evidence from Japan', Japanese Journal of Political Science, 16(1), pp. 5-32. doi: 10.1017/S146810991400036X.

Aspinall, E. and As'ad, M. U. (2016) 'Understanding family politics: Successes and failures of political dynasties in regional Indonesia', South East Asia Research, 24(3), pp. 420-435. doi: 10.1177/0967828X16659571.

Beetham, D. (1994) 'Conditions for democratic consolidation', Review of African Political Economy, 21(60), pp. 157-172. doi: 10.1080/03056249408704053.

Buehler, M. (2013) 'Married with children', Inside Indonesia, 112 (April. Available at: https://www.insideindonesia.org/married-with-children.

Buehler, M. and Tan, P. (2007) 'Party-Candidate Relationships in Indonesian Local Politics: A Case Study of the 2005 Regional Elections in Gowa, South Sulawesi Province', Indonesia, 84(84), pp. 41-69. 
Choi, N. (2007) 'Local elections and democracy in Indonesia: The Riau Archipelago Local Elections and Democracy in Indonesia: The Riau Archipelago', (October 2014), pp. 37-41. doi: 10.1080/00472330701408650.

cnnindonesia.com (2020a) 'OTT Bupati Kutai Timur Disebut Bukti Politik Dinasti Koruptif', 5 July. Available at: https://www.cnnindonesia.com/nasional/20200705025521-12-520915/ottbupati-kutai-timur-disebut-bukti-politik-dinasti-koruptif (Accessed: 7 February 2021).

cnnindonesia.com (2020b) 'PDIP di Pilkada 2020: Kader Tergusur, Politik Dinasti Berdiri', 2 September. Available at: https://www.cnnindonesia.com/nasional/20200901124256-32541531/pdip-di-pilkada-2020-kader-tergusur-politik-dinasti-berdiri.

van Coppenolle, B. (2017) 'Political Dynasties in the UK House of Commons: The Null Effect of Narrow Electoral Selection', Legislative Studies Quarterly, 42(3), pp. 449-475. doi: 10.1111/lsq.12164.

Crook, R. and Manor, J. (1998) Democracy and Decentralization in South Asia and West Africa. Cambridge: Cambridge University Press.

Dahl, R. (2000) On Democracy. New Haven \& London: University Press.

Dal Bó, E., Dal Bó, P. and Snyder, J. (2009) 'Political Dynasties', Review of Economic Studies, 76, pp. 115-142. Available at: http://dx.doi.org/http://dx.doi.org/10.2139/ssrn.909251.

Doyle, D. T. et al. (2015) 'Democratic Dynasties: Explaining Their Prevalence in Modern Democracies', SSRN Electronic Journal. doi: $10.2139 / \mathrm{ssrn} .2556830$.

Elklit, J. and Svensson, P. (1997) 'What Makes Elections Free and Fair?', Journal of Democracy, 8(3), pp. 32-46. doi: 10.1353/jod.1997.0041.

Fiva, J. H. and Smith, D. M. (2018) 'Political dynasties and the incumbency advantage in party-centered environments', American Political Science Review, 112(3), pp. 706-712. doi: 10.1017/S0003055418000047.

Geys, B. and Smith, D. M. (2017) 'Political Dynasties in Democracies: Causes, Consequences and Remaining Puzzles', Economic Journal, 127(605), pp. F446-F454. doi: 10.1111/ecoj.12442. 
Hadiz, V. R. (2004) 'Decentralisation and Democracy in Indonesia: A Critique of Neo-Institutional Perspectives', Development and Change, 35(4), pp. 697718. doi: 10.1111/j.0012-155X.2004.00376.x.

Hadiz, V. R. (2007) 'The Localization of Power in Southeast Asia', 14(5), pp. 873892.

Hadiz, V. and Robison, R. (2005) 'Neo-liberal Reforms and Illiberal Consolidations: The Indonesian Paradox', The Journal of Development Studies, 41, pp. 220-241. doi: 10.1080/0022038042000309223.

Hanif, H. and Pratikno (2012) 'Local Politics in Indonesia, 1999-2010: A Literature Review', PCD Journal, IV(1), pp. 181-209. Available at: https://doi.org/10.22146/pcd.25773.

Hutchcroft, P. and Rocamora, J. (2003) 'Strong Demands and Weak Institutions: The Origins and Evolution of the Democratic Deficit in the Philippines', Journal of East Asian Studies, 3. doi: 10.2307/23417680.

Kenawas, Y. C. (2017) 'The Institutional Foundation of the Emergence of Subnational Political Dynasties in Indonesia', Advances in Social Science, Education and Humanities Research (ASSEHR), 129, pp. 267-272. doi: 10.2991/icsps-17.2018.59.

Kenawas, Y. C. (2020) 'Mencermati Dinasti Politik di Indonesia', Diskusi Virtual Perludem. Available at: http://perludem.org/2020/06/19/materi-presentasidiskusi-virtual-perludem-mencermati-dinasti-politik-di-pilkada/.

Mariana, D. and Husin, L. H. (2017) 'Democracy, local election, and political dynasty in Indonesian politics', Jurnal Wacana Politik, 2(2), pp. 88-97. doi: 10.24198/jwp.v2i2.13998.

Mboi, A. B. (2009) 'Pilkada Langsung: The First Step on the Long Road to a Dualistic Provincial and District Government', in Erb, M. and Sulistiyanto, P. (eds) Deepening Democracy in Indonesia? Singapore: ISEAS, pp. 3849.

Mietzner, M. (2010) 'Indonesia's direct elections: Empowering the electorate or entrenching the New Order oligarchy?', in Greg, F. and Aspinall, E. (eds) Indonesia: The New Order and its Legacy. Canberra: ANU E- Press, pp. 173-190.

Nagara Institute (2020) Press Release: 124 Dinasti Politik Bertarung dalam Pilkada Serentak 2020 - Nagara Institute. Available at: https://nagarainstitute.com/pers-release-124-dinasti-politik-bertarungdalam-pilkada-serentak-2020/ (Accessed: 21 January 2021). 
OECD (2013) 'Trust in Government, Policy Effectiveness and the Governance Agenda', in Government at a Glance 2013. Paris: OECD Publishing (Government at a Glance), pp. 19-37. doi: https://doi.org/10.1787/gov_glance-2013-6-en.

Purdey, J., Aspinall, E. and As'ad, M. U. (2016) 'Understanding family politics', South East Asia Research, 24(3), pp. 420-435. doi: 10.1177/0967828X16659571.

Querubin, P. (2013) 'Political Reform and Elite Persistence: Term Limits and Political Dynasties in the Philippines *', Seminar Paper. Available at: https://sticerd.lse.ac.uk/seminarpapers/pspe10122013.pdf (Accessed: 27 January 2021).

Querubin, P. (2016) 'Family and Politics: Dynastic Persistence in the Philippines', Quarterly Journal of Political Science, 11(2), pp. 151-181. doi: 10.1561/100.00014182.

Rahmatunnisa, M. (2017) 'Mengapa integritas pemilu penting?', Jurnal Bawaslu, 3(1), pp. 1-11. Available at: http://www.bawaslu.go.id/sites/default/files/publikasi/01 JURNAL BAWASLU.pdf.

Randall, V. and Svåsand, L. (2002) 'Introduction: The Contribution of Parties to Democracy and Democratic Consolidation', Democratization, 9(3), pp. 110. doi: 10.1080/714000270.

Romli, L. (2008) 'Masalah Kelembagaan Partai Politik di Indonesia Pasca-Orde Baru', Jurnal Penelitian Politik, 5(1), pp. 21-30. doi: https://doi.org/10.14203/jpp.v5i1.494.

Rossi, M. (2016) Self-Perpetuation of Political Power: Evidence from a Natural Experiment in Argentina. 127. Available at: https://ideas.repec.org/p/sad/wpaper/127.html.

Rossi, M. A. (2009) The Causes of Political Dynasties in Democratic Countries *. Bogota. Available at: https://economia.uniandes.edu.co/sites/default/files/imagenes/eventos/Polit ical-Dynasties-Rossi.pdf (Accessed: 18 January 2021).

Schutt, R. K. (2012) 'Qualitative Data Analysis', in Investigating the Social World. 7th edn. Thousand Oaks, CA: SAGE Publications, Inc., pp. 320-357. Available at: http://jefftirshfield.com/wpcontent/uploads/2017/12/Investigating-the-Social-World_Schutt.pdf. 
Setyaningrum, D. and Saragih, H. A. (2019) 'Political Dynasties and the Moderating Role of Good Public Governance', Signifikan: Jurnal Ilmu Ekonomi, 8(2), pp. 135-144. doi: 10.15408/sjie.v8i2.11636.

Sulistiyanto, P. and Erb, M. (2009) 'Indonesia and The Quest for "Democracy",, in Erb, M. and Sulistiyanto, P. (eds) Deepening Democracy in Indonesia? Singapore: ISEAS, pp. 1-37.

Sutisna, A. (2017) 'The Proliferation Symptoms of Political Dinasties in Banten Under the Era of Governor Ratu Atut Chosiyah', Diponegoro Law Review, 2(2), p. 270. doi: 10.14710/dilrev.2.2.2017.26-42.

The Indonesian Institute (2020) Update Indonesia - Volume XIV, No.8 - Agustus 2020 (Bahasa Indonesia) | The Indonesian Institute. Available at: https://www.theindonesianinstitute.com/update-indonesia-volume-xiv-no8-agustus-2020-bahasa-indonesia/ (Accessed: 21 January 2021).

Tusalem, R. F. and Pe-Aguirre, J. J. (2013) 'The effect of political dynasties on effective democratic governance: Evidence from the Philippines', Asian Politics and Policy, 5(3), pp. 359-386. doi: 10.1111/aspp.12037.

voaindonesia.com (2020) 'Politik Dinasti di Pilkada, Refleksi Praktik Dinasti Partai Politik', 5 August. Available at: https://www.voaindonesia.com/a/politik-dinasti-di-pilkada-refleksipraktik-dinasti-partai-politik/5530642.html (Accessed: 18 February 2021).

Zheng, B. et al. (2016) 'An Electoral Model of Political Dynasties', SSRN Electronic Journal. doi: 10.2139/ssrn.2844004. 